\title{
HEART RATE MODULATIONS IN OVERTRAINING SYNDROME
}

\author{
Dejan Stanojevic ${ }^{1}$, Jelica Stojanovic Tosic ${ }^{2}$, Dusica Djordjevic ${ }^{2}$ \\ ${ }^{1}$ Special Hospital Merkur, Vrnjacka Banja, Serbia \\ ${ }^{2}$ Department of Physiology, Faculty of Medicine, University of Kragujevac, Kragujevac, Serbia
}

\section{MODULACIJE SRČANE FREKVENCE U SINDROMU PRETRENIRANOSTI}

\author{
Dejan Stanojević1, Jelica Stojanović Tosić2 , Dušica Đorđević² \\ ${ }^{1}$ Specijalna bolnica Merkur, Vrnjacka Banja, Srbija \\ ${ }^{2}$ Katedra za fiziologiju, Fakultet medicinskih nauka, Univerzitet u Kragujevcu, Kragujevac, Srbija
}

Received / Primljen: 30.08.2013.

Accepted / Prihvaćen: 14.09.2013.

\begin{abstract}
Every sports training program includes a component of repetitive overloading, but with an inadequate recovery time, such overloading may produce undesired effects, such as chronic fatigue and a lack of performance improvement. The state of underperformance known as the overtraining syndrome (OTS) is characterised by a number of physiological and psychological symptoms of maladaptation. It may take weeks, months or years to restore proper sports form after the development of OTS. Although overtraining has been studied for decades, the mechanism of overtraining and the tools for the early detection of overtraining are still not defined. In addition to other physiological, biochemical, immunological, psychological and performance markers, heart rate (HR) and its modulations are intensively investigated as a practical and reliable sign of overtraining. In general, resting bradycardia, a decrease in HR during submaximal exercise, an increase in speed of heart rate recovery and increased vagal-related heart rate variability indices are all well accepted markers of improved aerobic fitness. In contrast, changes of these HR measures in the opposite direction are commonly interpreted as indicators of detraining, chronic fatigue, non-functional overreaching or overtraining. However, based on the limited and diverse literature available, these parameters may be used for monitoring training status, optimising training programs and following the accumulation of fatigue, but their role in overtraining detection and assessment has yet to be elucidated. There is a need for well-controlled prospective studies where a longitudinal follow-up of athletes is performed. Because it is unethical to excessively train an athlete to produce OTS, an animal experimental model of OTS may advance our understanding of the "unexplained underperformance syndrome."
\end{abstract}

Keywords: overtraining, heart, heart rate, heart rate variability, heart rate recovery

\section{SAŽETAK}

Svaki program sportskog treninga se sastoji od ponavljanog preopterećenja, ali u nedostatku oporavka on može izazvati neželjene efekte kao što su odsustvo poboljšanja sportskog izvođenja i hronični umor. Ovo stanje pogoršane sportske forme, poznato kao sindrom pretreniranosti, je u vezi sa nizom fizioloških i psiholoških simptoma maladaptacije, a za obnovu sportske forme mogu biti potrebne nedelje, meseci, pa i godine. Iako se decenijama istražuje, mehanizam nastanka pretreniranosti, $i$ što je još važnije sredstva za rano otkrivanje pretreniranosti, još uvek nisu definisana. Pored ostalih fizioloških, biohemijskih, imunoloških, psiholoških $i$ markera sportskog izvođenja, srčana frekvencija i njeni modaliteti se intenzivno istražuju kao praktičan $i$ validan znak pretreniranosti. Generalno, bradikardija u miru, niža srčana frekvencija tokom vežbanja submaksimalnog intenziteta, brži oporavak srčane frekvence nakon vežbanja i povećanje indeksa varijabilnosti srčane frekvence povezanih sa povećanjem vagalnog tonusa, su znakovi poboljšanog aerobnog fitnesa. S druge strane, promene ovih srčanih parametara u suprotnom smeru se često smatraju indikatorima netreniranosti, hroničnog umora, nefunkcionalnog preopterećenja $i$ pretreniranosti. Na osnovu limitirane i raznolike dostupne literature, ovi parametri mogu biti predloženi za praćenje trenažnog statusa, poboljšanje trenažnih programa i praćenje akumuliranja umora, ali njihova uloga u detekciji i proceni pretreniranosti tek treba da bude objašnjena. Postoji velika potreba za kontrolisanim prospektivnim studijama u kojima bi se vršilo longitudinalno praćenje sportista, ali obzirom da je treniranje sportista na takav način da dodju u stanje pretreniranosti neetičko, dobar eksperimentalni životinjski model pretreniranosti bi mogao da pomogne u razumevanju ovog neobjašnjenog sindroma pada sportske forme.

Ključne reči: pretreniranost, srce, srčana frekvencija, varijabilnost srčane frekvencije, oporavak srčane frekvencije 
ABBREVIATIONS:

$$
\begin{array}{r}
\text { ANS - autonomic nervous system } \\
\text { FOR - functional overreaching } \\
\text { NFOR - nonfunctional overreaching } \\
\text { HR - heart rate } \\
\text { HRR - heart rate recovery }
\end{array}
$$

\section{BACKGROUND}

The modern training of athletes is based on the overload principle and the negative feedback theory: the training stimulus must be strong enough to induce a disturbance of homeostasis so that the body has to initiate reactions to adapt to the training stimulus (1). Continuous exposure of an athlete to training stress initiates structural and functional changes that enable the improvement of an athlete's sports performance (2). To achieve desired adaptations and reach a sports performance conditioning level, the training load on a single exercise session and on every micro-, meso- and macro-cycle of training must be adequately dosed. According to the contemporary understanding, in a well-planned and programmed training process, the intensity of training increases stepwise, the periods of rest between the bouts are sufficiently long to ensure regeneration of the muscle functions and the periods of rest are short enough to not allow the regression of supercompensation (3). Every advantageous training program included a component of repetitive overloading, but with an inadequate recovery time, such overloading may produce undesired effects, such as chronic fatigue and the absence of performance improvement (4). The lack of improvement in sports performance or a decrease in sports performance is characterised by a number of physiological and psychological signs and symptoms of maladaptation, and it may take weeks, months or years to restore proper sports form (5). This state of underperformance was previously described by terms such as burnout, staleness, failure adaptation, underrecovery, training stress syndrome, and chronic fatigue (6). Recent literature has used the terms overreaching (OR) and overtraining (OT). Many consider overreaching and overtraining as lying on a continuum (Table 1), but this may be an oversimplification (7). The difference between OR and OT is based on the time to recovery and not necessarily the degree or type of symptoms exhibited (8). Many recent articles have referred to the work of Kreider et al. (9) for the definition of OR and OT: OR/OT represents an accumulation of training and nontraining stress resulting in a short-term/long-term decrement in performance capacity with or without related physiological and psychological signs and symptoms of maladaptation in which the restoration of performance capacity may take several days to weeks or weeks to months. It should also be noted that the terms overreaching and overtraining refer to the stimulus, and the term overtraining syndrome (OTS) refers to the resulting condition (10). By using the expression "syndrome," the possibility of a multifactorial aetiology is acknowledged, in which exercise (training) is not the sole causal factor of the syndrome (5).

\section{DIAGNOSIS AND ASSESSMENT OF OVERTRAINING}

Some researchers have referred to overtraining as unexplained underperformance syndrome $(11,12)$. Currently, it appears that OTS represents a systemic inflammatory process with diffuse effects on the neurohormonal axis affecting host immunology and mood (8). Although in recent years the knowledge of central pathological mechanisms of overtraining has significantly increased, there is still a need to further study overtraining. The lack of improved sports performance or the decrease of sports performance is related to a number of physiological and psychological signs and symptoms of maladaptation. It may take weeks, months or years to restore proper sports form (5). The diagnosis of OTS is complicated by the fact that the clinical features are varied from one individual to another and are

\begin{tabular}{|l|l|l|l|l|}
\hline \multirow{2}{*}{ Training load } & \multicolumn{4}{|c|}{} \\
\cline { 3 - 5 } \cline { 3 - 4 } Outcome & Acute fatigue & $\begin{array}{l}\text { Functional } \\
\text { overreaching (FOR) }\end{array}$ & $\begin{array}{l}\text { Nonfunctional } \\
\text { overreaching (NFOR) }\end{array}$ & $\begin{array}{l}\text { Overtraining } \\
\text { Syndrome (OTS) }\end{array}$ \\
\hline Performance & Increase & Temporary decrement & Stagnation & Decrease \\
\hline Recovery & Day(s) & Days - weeks & Weeks - months & Months - ... \\
\hline
\end{tabular}

Table 1. Terminology from a joint consensus statement on overtraining

by the European College of Sport Science and the American College of Sports Medicine (5). 
nonspecific, anecdotal, and numerous (5). The only certain sign is a decrease in performance during competition or training (5). An excellent review of the topic published more than 20 years ago suggested more than 80 possible major symptoms in addition to performance decrements are involved (40 physiological, 12 psychological and information processing, 14 immunological and 18 biochemical symptoms) (13). Subsequent years of study have added to the list. Currently, several markers (hormones, performance test scores, psychological test scores, and biochemical and immune markers) are used, but none of these markers meet all the criteria for their use to be generally accepted (5). Many review articles have offered explanations for the mechanism behind the OTS $(5,6,12,14-24)$. Numerous hypotheses have been proposed for OTS (glycogen hypothesis, central fatigue hypothesis, glutamine hypothesis, oxidative stress hypothesis, autonomic nervous system hypothesis, hypothalamic hypothesis, cytokine hypothesis), each with strengths and weaknesses (6). Although these hypotheses have potential, they remain speculative until more prospective studies with longitudinal follow-ups are carried out. The definitive diagnosis of OTS requires the exclusion of organic diseases, infections, disorders, dietary caloric restriction, insufficient carbohydrate and/or protein intake, iron deficiency, magnesium deficiency, allergies, and so on (5). The identification of initiating events or triggers that lead to OTS is also important. One of the most certain triggers is a training error resulting in an imbalance between load and recovery. Other possible triggers are the monotony of training, too much competition, personal and emotional problems, sleep disturbance, altitude exposure, exercise heat stress, and so on. $(5,6)$. Because there is no diagnostic tool to identify an athlete experiencing OTS, the solution to the differential diagnosis can only be made by excluding all other possible causal factors for changes in performance and mood state. Therefore, if no explanation for the observed changes can be found, OTS is diagnosed (5).

\section{HEART RATE MODULATIONS IN OVERTRAINING SYNDROME}

The assessment of physiological parameters has been the primary method used to identify overtrained athletes (25). As previously mentioned, exercise is a biological stimulus to which the physiological systems, in particular the autonomic nervous system (ANS) and adrenal glands, respond during and after an exercise bout to maintain homeostasis (2). Because the ANS is connected to many other physiological systems, the responsiveness of the ANS may provide useful information about the functional adaptations of the body. It is well known that the ANS has a major effect on heart rate (HR), and the development of heart rate monitors has allowed further research into the mechanisms behind HR responses to exercise and adaptations to training (2). Technological advancements in portable and wearable systems for the real-time collection of physiological data provide new opportunities for computerised diagnostics and quantitative modelling in medicine and related sports applications. For example, modern sport watches with ECG-type sensors can be used not only for programming personalised training sessions but also for the simultaneous collection of beat-to-beat (RR) time series, with an accuracy comparable to clinical ECG equipment (26). Such personal RR data can be used for systematic heart rate variability (HRV) analysis to provide early indication of developing cardiac abnormalities, detection of overtraining and other purposes. Measurement of heart rate recovery (HRR) also has the potential to be a useful tool for monitoring fatigue and prescribing training load in well-trained and elite athletes (27).

$\mathrm{HR}$ and its modulation are primarily determined by the inotropic and chronotropic effects of both branches of the ANS on the myocardium and the sinus node $(28,29)$. Sympathetic stimulation increases heart rate, contractility and conduction velocity, whereas parasympathetic stimulation has the opposite effect (30). The adaptive responses of the cardiovascular system to regular physical activity appear to include a reduction in sympathetic activity and an increase in parasympathetic activity during rest and at different intensities of exercise (31-33). These traininginduced autonomic changes are coupled with a possible reduction in intrinsic heart rate, a decrease resting heart rate and an increase heart rate variability at rest (34-38). Athletes also show reduced sympathetic activity for any given submaximal work-rate compared with sedentary controls exercising at the same rate $(2,31,34)$ and have a more rapid heart rate recovery following exercise $(36,39)$. In contrast, changes to these HR measures in the opposite direction (increases in submaximal HR, decreases in HRR and/or decreases in vagal-related HRV indices) are commonly interpreted as indicators of detraining $(40,41)$, chronic fatigue, non-functional overreaching or overtraining $(2,28,42)$. Specifically, decreased sympathetic activation and parasympathetic dominance can lead to performance inhibition, fatigue, depression, and bradycardia (7, 43). However, it is worth noting that the interpretation of the changes in these HR measures is based on theoretical principles related to the expected ANS response to fatigue rather than on scientific evidence and that unexpected and/or unclear results have also been reported (44).

\section{RESTING HEART RATE}

The ANS plays a pivotal role in stress tolerance (17). The scientific and clinical literature suggests that overreaching and overtraining are concomitant with dysfunction of the hypothalamic-pituitary-adrenal (HPA) axis (45). Consequently, a negative adaptation to training stress potentially involves the ANS and may result in a concomitant alteration in HR (28). Increased resting HR is one of the first signs of OTS reported in the literature (46). The 
detection of elevated morning resting heart rate is taken by many sport practitioners as a practical method to detect early signs of NFOR and central nervous system fatigue (47-49). This assumption should be taken with care because the morning heart rate is influenced by many factors other than training (50). A number of studies investigated the effects of overtraining on resting heart rate, but changes to RHR do not appear to be consistently present when attempting to identify either overreaching or overtraining $(51,52)$. After applying physiological stress to induce OR or OTS, some studies found an elevation in RHR (47, 53-56), some found a decrease in RHR (57-59), and some reported no significant changes in $\operatorname{RHR}(60,61)$. Sleep provides a period of rest and restoration, and it may provide a more suitable setting for monitoring heart rate $(53,62)$. However, studies examining the effects of OR/OTS on the sleeping heart rate also yielded inconsistent results $(53,61-$ 63). A meta-analysis by Bosquet et al. (28) revealed a trivial increase in RHR, suggesting that it cannot be considered as a reliable sign of OTS. Interestingly, HR was moderately increased after short term interventions ( $<2$ weeks), and no significant alteration was found when the increase in training load was longer than 2 weeks (28). This time effect suggests that an increase in RHR may be used as a reliable sign of short-term fatigue (possibly FOR) but not long-term fatigue (possibly NFOR or OTS) (28). The analysis of these results should also account for the existence of two types of overtraining, sympathetic and parasympathetic, which result in different effects on heart rate. The sympathetic (Basedow type) overtraining syndrome is more common in anaerobic sports $(6,50)$ and is characterised by increased $\mathrm{HR}$ and blood pressure (BP); parasympathetic (Addison type) overtraining syndrome is more common in aerobic sports and is characterised by reduced $\mathrm{HR}$ and $\mathrm{BP}(50)$. It is suggested that sympathetic overtraining occurs during the early stages of OTS and the parasympathetic type occurs in the later, more severe stages of OTS (64).

\section{HEART RATE DURING EXERCISE}

During exercise, HR increases linearly with increasing workloads (65). A lower submaximal HR for the same exercise intensity is one of the most commonly observed adaptations to endurance training and is based on a number of adaptations: greater stroke volume, decreased sympathetic and increased parasympathetic activity, lower metabo-reflex activation because the muscles are more efficient at generating energy and reduced metabolite production (66). In addition, the lower sympathetic activity decreases the amount of catecholamines in circulation at a given workload, which contributes to a lower HR response (67). A comprehensive review of studies that investigated the effects of endurance training on HRmax involving a total of 314 subjects concluded that HRmax can decrease by $5-13$ beats/min with aerobic training and increase by 4-10 beats/min with tapering or detraining in some individuals
(65). The proposed mechanisms for explaining decreases in HRmax with training include plasma volume expansion, enhanced baroreflex function and decreased $ß$-adrenergic receptor number and density (2). Borresen and Lambert (2) indicated that an increase in at-rest HR and HR during submaximal exercise may serve as a diagnostic indication of overtraining. However, both submaximal and maximal HR have been shown to decrease when an athlete is overreached (68) or in the state of parasympathetic overtraining $(48,68,69)$. Under normal circumstances, a lower submaximal response is viewed as an increase in performance capacity (70), but these studies reveal that performance is compromised in such cases due to the negative effects of overtraining. Among the possible explanations for the decreased submaximal heart rates observed in these athletes are a decrease in sympathetic activation (70) and a decrease in p-adrenoreceptor density and/or sensitivity (48) as well as hypervolemia leading to increased stroke volume (68, 69). The decreased maximal heart rate values should be approached with some caution, as peripheral factors may be responsible for the termination of a maximal test before the true HR maximum is reached (68). Reduced maximal heart rates and other maximal physiological measures, such as oxygen uptake and blood lactate, after increased training may be the result of reduced sympathetic nervous system activity, decreased tissue responsiveness to catecholamines, and altered adrenergic receptor activity; such reductions may also simply be a consequence of a reduction in exercise time and a reduced power output achieved with maximal effort and not related to abnormalities per se (5).

\section{HEART RATE VARIABILITY}

Advancements in technology made it easy to assess the beat-to-beat variation in resting pulse rates, i.e., heart rate variability (HRV). Heart rate fluctuation may be considered an output variable of a feedback network that is continuously monitored and regulated by the ANS (33). HRV analysis is used as a measure of cardiac autonomic balance, with an increase in HRV indicating an increase in vagal (parasympathetic) tone relative to sympathetic activity (70). Power spectral analysis has shown that parasympathetic and sympathetic activity can be expressed at specific frequencies (71), with a very low-frequency, a lowfrequency and a high-frequency component. The occurrence of the very low-frequency component is unclear (33). However, the HF component is mediated by the parasympathetic system, and the LF component has been shown to be mediated by both sympathetic and parasympathetic modulation (71). For more than a decade, HRV has been suggested as a practical non-invasive method of assessing cardiac ANS status and possibly NFOR/OTS (72). This has lead researchers to suggest that HRV may be used to guide the training of elite athletes on a day-to-day basis (73-75). However, to date, studies that have investigated HRV and NFOR/OTS have revealed equivocal findings 
with increases $(57)$, decreases $(70,76)$ and no change $(52$, $59,68,61)$ shown in cardiac ANS activity. However, most spectral analysis studies support the theory that endurance training increases HRV, increases parasympathetic activity and, thus, contributes to a training bradycardia (31, 34, 77-79). The diversity of these results may be explained by a number of factors. First, the findings from the studies that have purposely attempted to induce NFOR/OTS are limited as it is difficult to differentiate between the three stages of the overtraining continuum (OR, NFOR and OTS). In contrast, studies that have investigated athletes that are already overtrained $(57,76)$ have not been able to provide baseline HRV values prior to the syndrome's onset, and this is important considering the intraindividuality of HRV recordings (80). Furthermore, day-to-day variability in HRV values is high due to the effects of environmental factors such as noise, temperature, light, and exercise (81), and most of these studies $(55,57,59,68,76)$ measured HRV on single, isolated and non-consecutive days. Finally, the methods by which HRV have been recorded vary in the literature (82); timing and body positioning also vary during recordings, with some studies investigating HRV during sleep and upon waking (76), using the supine to head-tilt method $(55,57,59,68)$, supine to-standing method $(83)$, or postexercise $(44,84)$.

\section{HEART RATE RECOVERY}

Heart rate recovery is the rate at which HR decreases (or the time taken for heart rate to recover) after the cessation of physical exercise (85-88). Passive post-exercise HRR is currently used in the assessment of endurance athletes to determine changes in performance or in the clinical setting as a predictor of all-cause mortality (89). HRR is dependent on the interaction between parasympathetic and sympathetic nervous activity, i.e., parasympathetic reactivation and sympathetic withdrawal. In fact, the rapid fall in heart rate after exercise appears to be a consequence of the prompt restoration of parasympathetic tone at the heart level, and the further decrease is attributed to the progressive decrease of sympathetic tone and hormonal factors $(71,90)$. A faster HRR reflects a positive adaptation to exercise training and possibly performance capacity (91-93). Changes in HRR and/or vagal-related HRV indices following training correlated largely with improvements in cardiorespiratory fitness-related performance variables, such as maximal aerobic speed and running/cycling performance $(27,83,94)$, as well as with improvement in the more neuromuscular-related performance parameter of repeated-sprint ability (95). Altered HRR kinetics have also been occasionally considered a marker of overreaching or overtraining $(13,96)$, but there are not enough data available in the literature to support this contention. For example, a sudden increase in the HRR of a trained cyclist was reported with a state of acute fatigue and/or a state of functional overreaching (96). Borresen and Lambert (44) showed that
HRR decreases with an increase in training load, and there was a tendency for a faster HRR with a decrease in training load. The authors speculated that the case in which the HRR decreased with an increase in training load can be explained by a sharp increase in the training load that produced symptoms of overreaching in the subjects. Interestingly, Buchheit et al. $(95,97)$ recently concluded that indices of HRR seem to be more sensitive markers of recently applied training loads than do indices of HRV, which reflect a long-term modulation of the autonomic nervous system with changes in training status. However, more recent work $(74,75,98)$ shows that HRV can also track fast changes in training status. Although HRR seems to be a promising tool for monitoring training status, this finding should be taken with care because there is no standard for measuring HRR. The methods used to determine heart rate recovery kinetics can differ dramatically from one study to another. Some studies have calculated time constants by fitting HR decay data to mathematical models $(27,98)$, and others have looked at the difference between peak heart rate and postexercise heart rate at a certain time after exercise (87, 99104). Exercise mode (cycling, running), intensity (maximal, submaximal), and the duration of the recovery period (one to five or more minutes) also greatly differ between studies. Buchheit et al. (105) found that HRR was faster after endurance exercise trials than after repeated sprint or high intensity exercise trials performed by the same subjects. It seems that there may be more than only parasympathetic factors involved in lowering heart rate after exercise, such as blood metabolites, type of previous exercise training and type of exercise during the assessment (i.e., anaerobic vs. aerobic), and so on.

\section{CONCLUSION}

Despite years of research, no single factor has been identified that can quantify how an individual responds to training or predict overtraining with accuracy. The usefulness of a physiological marker depends on the ease and frequency with which it can be measured and on the speed with which the results can be interpreted so that frequent monitoring is possible with little inconvenience to the athlete. The functional state of the autonomic nervous system may provide useful information about the overall functional adaptation of the body in response to a training stimulus because it is interlinked with many other physiological systems. In general, resting bradycardia, a decrease in HR during submaximal exercise, an increase in the speed of heart rate recovery and an increase in the vagal-related heart rate variability indices are well accepted markers of improved aerobic fitness. In contrast, changes in these HR measures in the opposite direction are commonly interpreted as indicators of detraining, chronic fatigue, nonfunctional overreaching or overtraining. However, all of these measurements are affected by the individuality of athletes and extraneous factors that limit their use as sen- 
sitive markers of training status. Based on the limited and diverse literature available, these parameters are proposed for monitoring training status, optimising training programs and following the accumulation of fatigue, but their role in overtraining detection and assessment has yet to be elucidated. There is a need for well-controlled prospective studies where a longitudinal follow-up of athletes is performed. Because it is unethical to excessively train an athlete to produce OTS, an animal experimental model of OTS may advance our understanding of the "unexplained underperformance syndrome."

\section{REFERENCES}

1. Seene T, Umnova M, Kaasik P. The exercise myopathy. In: Lehman M, et al., eds. Overload, perfomance incompetence, and regeneration in sport. New York: Kluwer Academic Plenum, 1999: 119-30.

2. Borresen J, Lambert MI. Autonomic control of heart rate during and after exercise - measurements and implications for monitoring training status. Sports Med 2008; 38 (8): 633-46.

3. Seene T, Kaasik P, Alev K, Pehme A, Riso EM. Composition and turnover of contractile proteins in volume-overtrained skeletal muscle. Int J Sports Med 2004; 25: 438-45.

4. Kadaja L, Eimre M, Paju K, et al. Impaired oxidative phosphorylation in overtrained rat myocardium. Exp Clin Cardiol 2010; 15 (4): e116-27.

5. Meeusen R, Duclos M, Foster C, et al. Prevention, diagnosis, and treatment of the overtraining syndrome: joint consensus statement of the European College of Sport Science and the American College of Sports Medicine. Med Sci Sports Exerc 2013; 45(1): 186-205.

6. Kreher JB, Schwartz JB. Overtraining syndrome: a practical guide. Sports Health 2012; 4 (2): 128-38.

7. Halson SL, Jeukendrup AE. Does overtraining exist? An analysis of overreaching and overtraining research. Sports Med 2004; 34 (14): 967-81.

8. Meeusen R, Duclos M, Gleeson M, et al. Prevention, diagnosis and treatment of the overtraining syndrome: ECSS position statement "task force". Eur J Sport Sci 2006; 6 (1): 1-14.

9. Kreider R, Fry AC, O’ Toole M. Overtraining in sport: terms, definitions, and prevalence. In: Kreider R, Fry AC, O’Toole M, eds. Overtraining in sport. Champaign (IL): Human Kinetics, 1998: VII-IX.

10. Fry AC, Steinacker JM, Meeusen R. Endocrinology of overtraining. In: Kraemer WJ, Rogol AD, eds. The endocrine system in sports and exercise. Oxford: Blackwell Publishing Ltd, 2005: 578-99.

11. Budgett R, Newsholme E, Lehmann M, et al. Redefining the overtraining syndrome as the unexplained underperformance syndrome. Br J Sports Med 2000; 34: 67-8.

12. Robson PJ. Elucidating the unexplained underperformance syndrome in endurance athletes: the interleukin-6 hypothesis. Sports Med 2003; 33: 771-81.
13. Fry RW, Morton AR, Keast D. Overtraining in athletes: an update. Sports Med 1991; 12: 32-65.

14. Meeusen R, Watson P, Hasegawa H, Roelands B, Piacentini MF. Brain neurotransmitters in fatigue and overtraining. Appl Physiol Nutr Metab 2007; 32 (5): 857-64.

15. Purvis D, Gonsalves S, Deuster PA. Physiological and psychological fatigue in extreme conditions: overtraining and elite athletes. PM R 2010; 2 (5): 442-50.

16. Roose J, de Vries WR, Schmikli SL, Backx FJ, van Doornen LJ. Evaluation and opportunities in overtraining approaches. Res Q Exerc Sport 2009; 80 (4): 756-64.

17. Brooks K, Carter J. Overtraining, exercise, and adrenal insufficiency. J Nov Physiother 2013; 3 (125):11717.

18. Smith LL. Cytokine hypothesis of overtraining: a physiological adaptation to excessive stress? Med Sci Sports Exerc 2000; 32: 317-31.

19. Smith LL. Tissue trauma: the underlying cause of overtraining syndrome? J Strength Cond Res 2004; 18 (1): 185-93.

20. Angeli A, Minetto M, Dovio A, Paccotti P. The overtraining syndrome in athletes: a stress-related disorder. J Endocrinol Invest 2004; 27 (6): 603-12.

21. Gleeson M. Biochemical and immunological markers of overtraining. J Sports Sci Med 2002; 1: 31-41.

22. Armstrong LE, Van Heest JL. The unknown mechanism of the overtraining syndrome: clues from depression and psychoneuroimmunology. Sports Med 2002; 32 (3): 185-209.

23. de Miranda Rohlfs ICP, de Mara LS, de Lima WC, de Carvalho T. Relationship of the overtraining syndrome with stress, fatigue, and serotonin. Rev Bras Med Esporte 2005 ; 11 (6): 333-7.

24. Wyatt FB, Donaldson A, Brown E. The overtraining syndrome: a meta-analytic review. J Exerc Physiol online 2013; 16(2): 12-23.

25. dos Santos Leite G, Sampaio LMM, Serra AJ, de Jesus Miranda ML, Ferreira MR, Brandão RBW. Analysis of knowledge production about overtraining associated with heart rate variability. J Exerc Physiol online 2012; 15 (2): 20-9.

26. Nunan D, Jakovljevic DG, Donovan G, Hodges LD, Sandercock GR, Brodie DA. Levels of agreement for RR intervals and short-term heart rate variability obtained from the Polar S810 and an alternative system. Eur J Appl Physiol 2008; 103 (5): 529-37.

27. Lamberts RP, Swart J, Capostagno B, Noakes TD, Lambert MI. Heart rate recovery as a guide to monitor fatigue and predict changes in performance parameters. Scand J Med Sci Sports 2010; 20: 449-57.

28. Bosquet L, Merkari S, Arvisais D, Aubert AE. Is heart rate a convenient tool to monitor over-reaching? A systematic review of the literature. Br J Sports Med 2008; 42 (9): 709-14.

29. Matelot D, Schnell F, Kervio G, Thillaye du Boullay N, Carré F. Athlete's bradycardia may be a multifactorial mechanism. J Appl Physiol 2013; 114 (12): 1755-6. 
30. Makivić B, Djordjević Nikić M, Willis MS. Heart rate variability (HRV) as a tool for diagnostic and monitoring performance in sport and physical activities. J Exerc Physiol online 2013; 16(3): 103-31.

31. Gregoire J, Tuck S, Yamamoto Y, Hughson RL. Heart rate variability at rest and exercise: influence of age, gender, and physical training. Can J Appl Physiol 1996; 21 (6): 455-70.

32. Oakley D. General cardiology: the athlete's heart. Heart 2001; 86 (6): 722-6.

33. Carter JB, Banister EW, Blaber AP. Effect of endurance exercise on autonomic control of heart rate. Sports Med 2003; 33 (1): 33-46.

34. Goldsmith RL, Bloomfeld DM, Rosenwinkel ET. Exercise and autonomic function. Coron Artery Dis 2000; 11: 129-35.

35. Shi X, Stevens GH, Foresman BH, Stern SA, Raven PB. Autonomic nervous system control of the heart: endurance exercise training. Med Sci Sports Exerc 1995; 27 (10): 1406-13.

36. Shin K, Minamitani H, Onishi S, Yamazaki H, Lee M. The power spectral analysis of heart rate variability in athletes during dynamic exercise: part 1. Clin Cardiol 1995; 18: 583-6.

37. Chen C, DiCarlo SE. Endurance exercise training-induces resting bradycardia: a brief review. Res Sports Med: Int J 1997; 8 (1): 37-77.

38. Wilmore JH, Stanforth P, Gagnon J, et al. Endurance exercise training has a minimal effect on resting heart rate: the HERITAGE study. Med Sci Sports Exerc 1996; 28 (7): 829-35.

39. Brenner IK, Thomas S, Shephard RJ. Spectral analysis of heart rate variability during heat exposure and repeated exercise. Eur J Appl Physiol 1997; 76: 145-56.

40. Mujika I, Padilla S. Cardiorespiratory and metabolic characteristics of detraining in humans. Med Sci Sports Exerc 2001; 33: 413-21.

41. Gamelin FX, Berthoin S, Sayah H, Libersa C, Bosquet L. Effect of training and detraining on heart rate variability in healthy young men. Int J Sports Med 2007; 28: 564-70.

42. Aubert AE, Seps B, Beckers F. Heart rate variability in athletes. Sports Med 2003; 33 (12): 889-919.

43. Lehmann M, Foster C, Keul J. Overtraining in endurance athletes: a brief review. Med Sci Sports Exerc1993; 25 (7): 854-62.

44. Buchheit M, Simpson MB, Al Haddad H, Bourdon PC, Mendez-Villanueva A. Monitoring changes in physical performance with heart rate measures in young soccer players. Eur J Appl Physiol 2012; 112 (2): 711-23.

45. Lehmann M, Foster C, Dickhuth HH, Gastmann U. Autonomic imbalance hypothesis and overtraining syndrome. Med Sci Sports Exerc 1998; 30: 1140-5.

46. Wolf W. A contribution to the questions of overtraining. Sportmed 1957; 2: 35.

47. Halson SL, Bridge MW, Meeusen R, et al. Time course of performance changes and fatigue markers during intensified training in trained cyclists. J Appl Physiol 2002; 93 (3): 947-56.
48. Lehmann M, Baumgartl P, Wiesenack C, et al. Training-overtraining: influence of a defined increase in training volume vs training intensity on performance, catecholamines and some metabolic parameters in experienced middle- and long-distance runners. Eur J Appl Physiol Occup Physiol 1992; 64 (2): 169-77.

49. Dressendorfer RH, Wade CE, Scaff JH. Increased morning heart rate in runners : a valid sign of overtraining? Phys Sportsmed 1985; 13: 77-86.

50. Nigam AK. Resting heart rate and overtraining in athletes. Int Referred Res J 2010; 2 (21): 38-40.

51. Urhausen A, Kindermann W. Diagnosis of overtraining: what tools do we have? Sports Med 2002; 32: 95-102.

52. Achten J, Jeukendrup AE. Heart rate monitoring: applications and limitations. Sports Med 2003; 33: 517-38.

53. Jeukendrup AE, Hesselink MK, Snyder AC, Kuipers H, Keizer HA. Physiological changes in male competitive cyclists after two weeks of intensified training. Int J Sports Med 1992; 13 (7): 534-41.

54. Dressendorfer RH, Hauser AM, Timmis GC. Reversal of runner's bradycardia with training overstress. Clin J Sport Med 2000; 10 (4): 279-85.

55. Pichot V, Roche F, Gaspoz JM, et al. Relation between heart rate variability and training load in middledistance runners. Med Sci Sports Exerc 2000; 32 (10): 1729-36.

56. Pichot V, Busso T, Roche F, et al. Autonomic adaptations to intensive and overload training periods: a laboratory study. Med Sci Sports Exerc 2002; 34 (10): 1660-6.

57. Hedelin R, Wiklund U, Bjerle P, Henriksson-Larsén K. Cardiac autonomic imbalance in an overtrained athlete. Med Sci Sports Exerc 2000; 32 (9): 1531-3.

58. Uusitalo AL, Uusitalo AJ, Rusko HK. Endurance training, overtraining and baroreflex sensitivity in female athletes. Clin Physiol 1998; 18 (6): 510-20.

59. Uusitalo AL, Uusitalo AJ, Rusko HK. Exhaustive endurance training for 6-9 weeks did not induce changes in intrinsic heart rate and cardiac autonomic modulation in female athletes. Int J Sports Med 1998; 19 (8): 532-40.

60. Flynn MG, Carroll KK, Hall HL, Bushman BA, Brolinson PG, Weideman CA. Cross training: indices of training stress and performance. Med Sci Sports Exerc 1998; 30 (2): 294-300.

61. Bosquet L, Papelier Y, Léger L, Legros P. Night heart rate variability during overtraining in male endurance athletes. J Sports Med Phys Fitness 2003; 43 (4): 506-12.

62. Callister R, Callister RJ, Fleck SJ, Dudley GA. Physiological and performance responses to overtraining in elite judo athletes. Med Sci Sports Exerc 1990; 22 (6): 816-24.

63. Portier H, Louisy F, Laude D, Berthelot M, Guézennec CY. Intense endurance training on heart rate and blood pressure variability in runners. Med Sci Sports Exerc 2001; 33 (7): 1120-5.

64. Kuipers H. Training and overtraining: An introduction. Med Sci Sports Exerc 1998; 30 (7): 1137 -9.

65. Zavorsky GS. Evidence and possible mechanisms of alteled maximum heart rate with endurance training and tapering. Sports Med 2000; 29 (1): 13-26. 
66. Mostoufi-Moab S, Widmaier EJ, Cornett JA, Gray K, Sinoway LI. Forearm training reduces the exercise pressor reflex during ischemic rhithmic handgrip. J Appl Physiol 1998; 84 (1): 277-83.

67. Cousineau D, Ferguson RJ, de Champlain J, Gauthier P, Côté P, Bourassa M. Catecholamines in coronary sinus during exercise in man before and after training. J Appl Physiol 1977; 43 (5): 801-6.

68. Hedelin R, Kenttä G, Wiklund U, Bjerle P, HenrikssonLarsén K.Shorterm overtraining: effects on performance, circulatory responses, and heart rate variability. Med Sci Sports Exerc 2000; 32 (8): 1480-4.

69. Snyder AC, Kuipers H, Cheng B, Servais R, Fransen E. Overtraining following intensified training with normal muscle glycogen. Med Sci Sports Exerc 1995; 27 (7): 1063-70.

70. Uusitalo AL, Uusitalo AJ, Rusko HK. Heart rate and blood pressure variability during heavy training and overtraining in the female athlete. Int J Sports Med 2000; 21: 45-53.

71. Perini R, Veicsteinas A. Heart rate variability and autonomic activity at rest and during exercise in various physiological conditions. Eur J Appl Physiol 2003; 90 (3-4): 317-25.

72. Plews DJ, Laursen PB, Kilding AE, Buchheit M. Heart rate variability in elite triathletes, is variation in variability the key to effective training? A case comparison. Eur J Appl Physiol 2012; 112 (11): 3729-41.

73. Hautala AJ, Kiviniemi AM, Tulppo MP. Individual responses to aerobic exercise: the role of the autonomic nervous system. Neurosci Biobehav Rev 2009; 33 (2): 107-15.

74. Kiviniemi AM, Hautala AJ, Kinnunen H, et al. Daily exercise prescription on the basis of hr variability among men and women. Med Sci Sports Exerc 2010; 42: 1355-63.

75. Kiviniemi AM, Hautala AJ, Kinnunen H, Tulppo MP. Endurance training guided individually by daily heart rate variability measurements. Eur J Appl Physiol 2007; 101 (6): 743-51.

76. Hynynen E, Uusitalo A, Konttinen N, Rusko H. Heart rate variability during night sleep and after awakening in overtrained athletes. Med Sci Sports Exerc 2006; 38(2): 313-17.

77. Grant CC, Janse van Rensburg DC. The effect of different types of sports on resting heart rate variability and autonomic nervous system balance. Afr J Physical, Health Educ, Recr, Dance 2008; 14 (3): 326-336.

78. Dixon EM, Kamath MV, McCartney N, Fallen EL. Neural regulation of heart rate variability in endurance athletes and sedentary controls. Cardiovasc Res 1992; 26: 713-9.

79. Furlan R, Piazza S, Dell'Orto S, et al. Early and late effects of exercise and athletic training on neural mechanisms controlling heart rate. Cardiovasc Res 1993; 27: 482-8.

80. Al Haddad H, Laursen PB, Chollet D, Ahmaidi S, Buchheit M. Reliability of resting and postexercise heart rate measures. Int J Sports Med 2011; 32 (8): 598-605.
81. Earnest CP, Jurca R, Church TS, Chicharro JL, Hoyos J, Lucia A. Relation between physical exertion and heart rate variability characteristics in professional cyclists during the Tour of Spain. Br J Sports Med 2004; 38 (5): 568-75.

82. Mourot L, Bouhaddi M, Perrey S, et al. Decrease in heart rate variability with overtraining: assessment by the Poincaré plot analysis. Clin Physiol Funct Imaging 2004; 24 (1): 10-8.

83. Hynynen E, Uusitalo A, Konttinen N, Rusko H. Cardiac autonomic responses to standing up and cognitive task in overtrained athletes. Int J Sports Med 2008; 29 (7): 552-8.

84. Buchheit M, Chivot A, Parouty J, et al. Monitoring endurance running performance using cardiac parasympathetic function. Eur J Appl Physiol 2010; 108 (6): 1153-67.

85. Pierpont GL, Voth EJ. Assessing autonomic function by analysis of heart rate recovery from exercise in healthy subjects. Am J Cardiol 2004; 94 (1): 64-8.

86. Borresen J, Lambert MI. Changes in heart rate recovery in response to acute changes in training load. Eur J Appl Physiol 2007; 101: 503-11.

87. Lamberts RP, Swart J, Noakes TD, Lambert MI. Changes in heart rate recovery after high-intensity training in welltrained cyclists. Eur J Appl Physiol 2009; 105: 705-13.

88. Shetler K, Marcus R, Froelicher VF, et al. Heart rate recovery: validation and methodologic issues. J Am Coll Cardiol 2001; 38: 1980-7.

89. Bosquet L, Gamelin FX, Berthoin S. Reliability of postexercise heart rate recovery. Int J Sports Med 2008; 29 (3): 238-43.

90. Arai Y, Saul JP, Albrecht P, et al. Modulation of cardiac autonomic activity during and immediately after exercise. Am J Physiol 1989; 256: H132-41.

91. Daanen HA, Lamberts RP, Kallen VL, Jin A, Van Meeteren NL. A systematic review on heart-rate recovery to monitor changes in training status in athletes. Int J Sports Physiol Perform 2012; 7 (3): 251-60.

92. Yamamoto K, Miyachi M, Saitoh T, Yioshioka A, Onodera $\mathrm{S}$. Effects of endurance training on resting and post exercise cardiac autonomic control. Med Sci Sports Exerc 2001; 33: 1496-502.

93. Sugawara J, Murakami H, Maeda S, Shinya K, Matsuda $M$. Change in post exercise vagal reactivation with exercise training and detraining in young men. Eur J Appl Physiol 2001; 85: 259-263.

94. Lamberts RP, Lambert MI. Day-to-day variation in heart rate at different levels of submaximal exertion: implications for monitoring training. J Strength Cond Res 2009; 23: 1005-10.

95. Buchheit M, Millet GP, Parisy A, Pourchez S, Laursen $\mathrm{PB}$, Ahmaidi S. Supramaximal training and post-exercise parasympathetic reactivation in adolescents. Med Sci Sports Exerc 2008; 40: 362-71.

96. Lamberts RP, Rietjens GJ, Tijdink HH, Noakes TD, Lambert MI. Measuring submaximal performance parameters to monitor fatigue and predict cycling performance: a case study of a world-class cyclo-cross cyclist. Eur J Appl Physiol 2010; 108: 183-90. 
97. Buchheit M, Papelier Y, Laursen PB, Ahmaidi S. Noninvasive assessment of cardiac parasympathetic function: postexercise heart rate recovery or heart rate variability? Am J Physiol Heart Circ Physiol 2007; 293: H8-H10.

98. Imai K, Sato H, Hori M, et al. Vagally mediated heart rate recovery after exercise is accelerated in athletes but blunted in patients with chronic heart failure. J Am Coll Cardiol 1994; 24: 1529-35.

99. Heffernan KS, Fahs A, Shinsako KK, Jae SY, Fernhall B. Heart rate recovery and heart rate complexity following resistance exercise training and detraining in young men. Am J Physiol Heart Circ Physiol 2007; 293: H3180-6.

100. Cheng YJ, Lauer MS, Earnest CP, et al. Heart rate recovery following maximal exercise testing as a predictor of cardiovascular disease and all-cause mortality in men with diabetes. Diabetes Care 2003; 26: $2052-7$.
101. Cole CR, Blackstone EH, Pashkow FJ, Snader CE, Lauer MS. Heart-rate recovery immediately after exercise as a predictor of mortality. N Engl J Med 1999; 341: 1351-7.

102. Cole CR, Foody JM, Blackstone EH, Lauer MS. Heart rate recovery after submaximal exercise testing as a predictor of mortality in a cardiovascular healthy cohort. Ann Intern Med 2000; 132: 552-5.

103. Jouven X, Empana JP, Schwartz PJ, Desnos M, Courbon D, Ducimetiere P. Heart rate profile during exercise as a predictor of sudden death. New Engl J Med 2005; 352: 1951-8.

104. Nishime EO, Cole CR, Blackstone EH, Pashkow FJ, Lauer MS. Heart reate recovery and treadmill exercise scores as predictors of mortality in patients referred for exercise ECG. JAMA 2000; 284: 1392-8.

105. Buchheit M, Laursen PB, Al Haddad H, Ahmaidi S. Exercise induced plasma volume expansion and postexercise parasympathetic reactivation. Eur J Appl Physiol 2009; 105 (3): 471-81. 